University of Nebraska - Lincoln

DigitalCommons@University of Nebraska - Lincoln

Public Health Resources

Public Health Resources

2006

Graduated Driver Licensing and Teenage Driver Research in 2006

James Hedlund

Highway Safety North, USA

Ruth Schults

Centers for Disease Control and Prevention, USA

Richard Compton

National Highway Traffic Safety Administration, USA

Follow this and additional works at: https://digitalcommons.unl.edu/publichealthresources

Part of the Public Health Commons

Hedlund, James; Schults, Ruth; and Compton, Richard, "Graduated Driver Licensing and Teenage Driver Research in 2006" (2006). Public Health Resources. 84.

https://digitalcommons.unl.edu/publichealthresources/84

This Article is brought to you for free and open access by the Public Health Resources at DigitalCommons@University of Nebraska - Lincoln. It has been accepted for inclusion in Public Health Resources by an authorized administrator of DigitalCommons@University of Nebraska - Lincoln. 


\title{
Graduated driver licensing and teenage driver research in 2006
}

\author{
James Hedlund ${ }^{\mathrm{a}, *}$, Ruth A. Shults ${ }^{\mathrm{b}}$, Richard Compton ${ }^{\mathrm{c}}$ \\ ${ }^{a}$ Highway Safety North, USA \\ ${ }^{\mathrm{b}}$ Centers for Disease Control and Prevention, USA \\ ${ }^{\mathrm{c}}$ National Highway Traffic Safety Administration, USA \\ Received 15 February 2006; accepted 15 February 2006 \\ Available online 27 March 2006
}

\begin{abstract}
This is the third update of research on graduated driver licensing (GDL) and related teenage driver issues. It briefly summarizes research published since or not included in the 2005 update (Hedlund, J., \& Compton, R. (2005). Graduated driver licensing research in 2004 and 2005. Journal of Safety Research, 36(2), 109-119.), describes research in progress of which the authors are aware, and announces plans for a symposium on teenage driving and GDL to be held in February 2007.
\end{abstract}

Keywords: Graduated driver licensing; Beginning drivers; Teenage drivers; Driver education

\section{Introduction}

The January 2003 special issue of the Journal of Safety Research was devoted entirely to graduated driver licensing (GDL). The first 12 papers, written for and presented at a GDL symposium in November 2002, provided a comprehensive review of research on teenage drivers with an emphasis on GDL. The final paper (Hedlund, Shults, \& Compton, 2003) used information from these papers to summarize GDL knowledge, information gaps, and research needs as of the time of the symposium. All papers are available on the National Safety Council's website www.nsc.org/gdlsym/index.htm.

There has been substantial research on GDL and teenage drivers since the 2002 symposium. Hedlund and Compton $(2004,2005)$ provide annual summaries of newly-published results and work in progress. This paper is the third annual update. It briefly summarizes research published since or not included in the 2005 update and lists research in progress or planned. Published research was obtained from a keyword search of Medline, PsycInfo, ERIC, TRIS, NTIS,

\footnotetext{
* Corresponding author.

E-mail address: jhedlund@sprynet.com (J. Hedlund).
}

Wilson Applied Science and Technology Abstracts, and EMBASE, supplemented by information provided by the authors and several reviewers.

\section{What is GDL and where has it been implemented?}

GDL is a three-stage licensing system for beginning drivers consisting of a learner's permit, an intermediate license, and a full license. A learner's permit allows driving only while supervised by a fully licensed driver. An intermediate license allows unsupervised driving under certain restrictions. Both the learner's permit and the intermediate license have a minimum age requirement and must be held for a specified minimum period of time.

Other restrictions or requirements may apply during the learner's permit and intermediate license periods. The most common are that learner's permit drivers may be required to have a minimum amount of supervised driving before advancing to the intermediate phase, and intermediate license drivers may be prohibited from driving during specified nighttime hours or with young passengers. For a full discussion of GDL systems, requirements and restrictions, and recommended practices see Insurance Institute for Highway Safety (IIHS) and Traffic Injury Research Foun- 
dation (TIRF; 2004) or Mayhew, Simpson, and Singhal (2005).

Almost all jurisdictions in the United States and Canada have implemented GDL in some form. The GDL requirements in all jurisdictions as of October 2005 are summarized in IIHS (2005) for the United States and Mayhew et al. (2005) for Canada. The National Committee on Uniform Traffic Laws and Ordinances provides a model GDL law (NCUTLO, 2002).

\section{Syntheses and overviews}

\subsection{Extensive syntheses}

Mayhew et al. (2005) contains a detailed description of current GDL programs in Canada; a comparison with GDL programs in other countries, including tabular summaries of GDL provisions in Canadian provinces, states in the United States, Australian states, and New Zealand; a description of the safety benefits of GDL, including a tabular summary of effectiveness estimates from evaluations and a discussion of the features that have been shown to contribute to GDL effectiveness; and recommendations for best practices.

Senserrick and Haworth (2005) provide a comprehensive review of driver education and training, licensing, and GDL, with well over 300 references. They provide specific recommendations for Western Australia.

Simons-Morton, Mickalide, and Olsen (2005) summarize research on young driver crash and injury rates; risk factors, including age, inexperience, nighttime driving, passengers, safety belt use and alcohol; and prevention strategies, including GDL and parental management.

Simons-Morton and Winston (2006) discuss GDL and parental management of young drivers as examples of how research translates into action by informing and influencing policy.

The Organization for Economic Co-operation and Development (OECD) has established a working group on Young Driver Risks and Effective Counter-Measures. The working group is assessing the factors that contribute to young drivers' crash risks; reviewing countermeasures, including driver education, driver training, and GDL; and documenting current practices in the OECD countries. A final report is scheduled for release in 2006. For information, contact Colin Stacey at Colin.STACEY@oecd.org.

The Highway Safety Research Center (HSRC) at the University of North Carolina is drafting a guide for states to use in reducing crashes involving young drivers. The guide is part of the series of state guides for implementation of the American Association of State Highway and Transportation Officials (AASHTO) strategic plan. Each guide is a volume in the National Cooperative Highway Research Program (NCHRP) Report 500. The young driver guide should be completed in 2006. For information, contact Rob Foss at foss@hsrc.unc.edu.
The Centers for Disease Control and Prevention (CDC), the National Institutes of Health (NIH), and the National Highway Traffic Safety Administration (NHTSA) are cofunding a National Research Council scoping study to examine new insights from the behavioral, cognitive, health, social, and biological sciences, especially in the area of adolescent development and learning processes, that may guide prevention strategies to reduce motor-vehicle crash rates. The study will examine diverse scientific literatures, including research on adolescent health and development, decision making research, parental and family processes, education, risk communication, public health, human factors studies, highway safety, motor-vehicle injuries, public policy, and related fields. The scoping study should be completed by late 2006. For information, contact Ruth Shults at rshults@cdc.gov.

The United Kingdom Department for Transport is funding an extensive review of the judgment and decision making literature to investigate potential road safety applications to adolescents. Victor Strecher and Jean Shope expect their review of psychosocial factors and behavioral science theoretical frameworks to be available in 2006. For information, contact Deirdre.O'Reilly@dft. gsi.gov.uk.

\subsection{Brief overviews and commentary}

Williams (2005) observed that by 2005 the first phase of GDL implementation was essentially complete in the United States and Canada, with most jurisdictions having some form of GDL in place. In the next phase, jurisdictions with weak GDL systems should strengthen them. He noted that 15 states have improved their initial GDL systems but that as of 2005 no state had an "excellent" system consisting of a minimum learner age of 16, a 6-month learner's permit holding period, and intermediate license restrictions on nighttime driving (beginning at 9 p.m.) and carrying more than one young passenger, with intermediate restrictions in place until age 18 .

Stevenson (2005) observed that Australian GDL systems have no nighttime or passenger restrictions for intermediate license holders. He recommends that they be added.

McKay (2005) briefly reviewed teenage driver crash risks and advocates GDL with nighttime and passenger restrictions as well as safety belt use, not drinking and driving, and safer vehicles.

\section{The need for GDL: teenage driver risk factors}

Risk factor study methods include cohort studies, focus groups, telephone surveys, questionnaires, crash data analyses, and experimental studies. They provide additional detail on the influences of general lifestyle and of specific individual and environmental factors on teenage driver crash risk. 


\subsection{Teenage driver crash risks}

Williams, Ferguson, and Wells (2005) used Fatality Analysis Reporting System (FARS) data to investigate fatal crashes involving 16-year-old drivers in the United States from 1993 to 2003. During this period 46 states and the District of Columbia introduced important GDL components. The per capita fatal crash rate for 16-year-old drivers decreased 26\% from 1993 to 2003 compared to $11 \%$ for 17 year-old drivers, $6 \%$ for 1819 year-old-drivers, and $7 \%$ for 20-49 year-old drivers. Fatal crashes per licensed driver did not change for 16-, 17-, or 18-year-old drivers. There was a substantial decrease in fatal crashes in which 16-year-old drivers had teenage passengers but no change in late-night fatal crashes.

O'Malley and Johnston (2003) summarized data from the annual Monitoring the Future surveys from 1976-2001. In $2000-2001,32 \%$ of high school seniors in the United States reported receiving a traffic ticket or warning in the past year and $22 \%$ were involved in a crash. Over the 25 -year period, the annual proportion who received tickets increased slightly while the proportion involved in a crash remained relatively stable. When adjusted for miles of travel, both proportions decreased over time. Crashes after drinking decreased markedly from 1981 to 2001 . Crashes after using marijuana peaked in 1979, decreased substantially over the next decade, and then rose again in the 1990s.

AAA (2006) studied fatal crashes involving drivers aged 15, 16, and 17 using FARS data from 1995-2004. Of the 30,917 persons who died in these crashes, about one-third were the teen drivers themselves $(36 \%)$, one-third were passengers of these teen drivers $(32 \%$, almost all of whom were under 21 years old), and the remainder were other vehicle occupants $(24 \%)$ and nonmotorists $(8 \%)$.

Gonzales, Dickinson, DiGuiseppi, and Lowenstein (2005) studied fatal crashes involving 16-year-old drivers in Colorado, using FARS data from 1995 to 2001. Compared to drivers aged 25-49, 16-year-old drivers in fatal crashes were more likely to be reported as speeding or driving recklessly, more likely to be in a rollover, run-offroad, or single vehicle crash, and more likely to have two or more passengers, but less likely to have been drinking. Almost half the drivers in both groups were not wearing safety belts.

Aultman-Hall and Padlo (2004) studied crashes involving drivers aged 16-20 in Connecticut, using state crash data from 1997-2001. With the use of quasi induced exposure techniques, they concluded that the risk of causing a crash for these drivers increases at night, on freeways, and with passengers. The youngest drivers and male drivers also had substantially higher crash risks.

Adams (2005) compared overall crash rates and crash distributions by hour for intermediate-stage drivers and fully-licensed drivers aged 19-59 in Western Australia. She found that both fatal and hospitalization crash rates per population were about seven times higher for intermediate stage drivers, both overall and for male and female drivers separately. Intermediate-stage drivers had a higher proportion of crashes at night. Western Australia has no nighttime restriction for intermediate stage drivers.

Bellavance et al. (2005) reviewed the literature on psychological factors underlying teenage risk-taking, factors that predict risky behavior, and methods to evaluate the attitudes and driving behaviors of beginning drivers. The 525-page review is available at www.hec.ca/pages/francois. bellavance/Nouveaux-conducteurs.pdf. The authors are preparing shorter summaries in English for journal publication. For information, contact François Bellavance at francois. bellavance@hec.ca.

IIHS and TIRF have reviewed studies since 1990 on the relative effects of age and experience on crash risk, especially for young drivers. The report should be released in spring 2006. For information, contact Anne McCartt at AMcCartt@iihs.org.

The Preusser Research Group (PRG) is studying crashes during the first few months of driving. The study, sponsored by IIHS, should be released in 2006. For information, contact Susan Ferguson at sferguson@iihs.org.

Rhodes and colleagues at the University of Alabama Injury Control Research Center are conducting a five-year study to develop and test risk-taking countermeasures for drivers aged 16-20. Initial information on crash risks and teenage driver attitudes obtained from analyses of Alabama crash data and from a series of focus groups with young drivers are summarized in Rhodes, Brown, and Edison (2005).

In a study funded by CDC, The University of Michigan Transportation Research Institute (UMTRI) will use existing longitudinal data to identify risk and protective factors related to crashes involving teenage drivers. Information about the psychosocial and problem behavior development of a large cohort of public school students who were followed from the 5 th through the 12 th grade will be merged with their state drivers license history records and police crash report records. The study will identify types of crashes for which teens are at greater risk than adult drivers, and examine individual psychosocial risk and protective factors that predict the high-risk crash types among teen drivers. For information, contact Ruth Shults at rshults@cdc.gov.

CDC will convene an expert panel to identify and critically assess existing datasets that provide information on adolescent motor-vehicle related crashes, injuries, and fatalities. This panel will bring together experts in such areas as transportation, health outcomes, insurance costs, and health care utilization. A report will summarize the different existing datasets, critically assess their strengths and weaknesses, identify gaps, and propose linkages. The report should be available by late 2006. For information, contact Ruth Shults at rshults@cdc.gov.

The National Institute of Child Health and Human Development is beginning a multi-year naturalistic driving 
study of teenagers during their first 18 months of licensure. The study, conducted by the Virginia Tech Transportation Institute, will equip the cars of 24 teenage drivers with cameras, motion sensors, global positioning instrumentation, and other devices to measure and record driving performance. Initial data will be available in 2007. For information, contact Bruce Simons-Morton at mortonb@ exchange.nih.gov.

\subsection{Sociodemographic characteristics}

Paschall (2003) studied the relation between college attendance and two risky driving behaviors - safety belt use and drinking and driving - in a sample of 11,549 college-age youth from the National Household Survey on Drug Abuse (NHSDA). He found that college students were more likely to drink and drive but also more likely to wear safety belts than non-students, after controlling for other factors related to these behaviors.

Elliott, Shope, Raghunathan, and Waller (2006) investigated associations between gender, substance use, environmental factors that may affect substance use (peers, parents, and ease of access), and risky driving behavior in a longitudinal study of 4,022 high school students in Michigan. Overall, young women had lower levels of substance use and less risky driving (measured by serious traffic offenses and crashes) than young men. At every level of substance use, men had higher levels of risky driving than women. However, substance use and environmental factors were more closely associated with risky driving among young women than young men. For example, as substance use levels increased, risky driving increased more for women than for men.

In three related studies, Laflamme and colleagues investigated sociodemographic characteristics associated with young drivers' crashes in Sweden using crash records from 1988-2000 for all persons born in 1970-1972. Hasselberg and Laflamme (2005) found that young drivers who sustained more than one crash injury in an 8-year period did not differ from drivers who sustained only one injury with regard to gender, education, or socioeconomic group. Vaez and Laflamme (2005) found that among all drivers less than 30 years of age who were involved in crashes, the odds of severe injury were higher for the youngest drivers, for drivers who were impaired by alcohol, and for drivers with less education. Males and drivers with the least education were most likely to have been impaired by alcohol. Laflamme, Vaez, Hasselberg, and Kullgren (2005) examined how the interaction between a driver's socioeconomic status and the safety of the driver's car affects injury risk. For drivers of cars in each of five crash safety groups determined by Folksam insurance, injury risk was higher for males and for less-educated drivers. This suggests that safer vehicles reduce crash injuries for all socioeconomic groups and do not reduce injury risk differentials across groups.

\subsection{Attitudes and personality}

\subsubsection{Attitudes and behavior regarding risk}

Clarke, Ward, and Truman (2005) studied 3,437 crash reports from the United Kingdom involving drivers aged 17-25 from the years 1994-1996. Based on interpretation of the individual crash reports, crashes of all types were more frequently due to voluntary risky behaviors than to lack of driving skills such as failure to observe potential hazards.

Harré, Foster, and O’Neill (2005) studied "crash-risk optimism" - the view that while a behavior is risky for others, it's not risky for me - and how these beliefs are related to young drivers' reactions to traffic safety messages. In a survey, 314 New Zealand students aged 16-29 generally rated themselves better than their peer drivers on measures of both driving skill and driving caution. In a second study, 266 students viewed traffic safety television ads that were either highly graphic, with crashes and injuries resulting from drinking and driving, or positive, showing people taking measures to avoid driving after drinking. The students then took the crash-risk optimism survey. Students who watched the graphic ads rated themselves better on driving skill than the students who watched the other spots. This suggests that some young drivers may dissociate themselves from the types of driving behavior depicted in graphic traffic safety ads, so that graphic ads may have little effect on them. In both groups, men rated their driving skill higher than did women.

Victoir, Eertmans, Van den Bergh, and Van den Broucke (2005) studied how beginning drivers' attitudes, norms, and intentions predicted their driving performance in a 90 minute on-road driving session. Ninety-eight Flemish drivers, average age 22, participated in the study. A model based on the theory of planned behavior predicted performance as evaluated both by the participants themselves and by instructors. Driving confidence (or self-efficacy - a driver's belief that he or she is able to control the car, anticipate risks, and the like) was the most important single predictor of performance.

Tilleczek (2004) studied and described the youth driving culture in a northern Ontario community using a survey and direct observations of 88 novice drivers aged 15-34. The results suggest that youth are aware of the risks of driving and intend to drive safely. However, the "system" does not encourage safe driving when it characterizes youth as risk-takers and blames individuals for risky actions.

Sarkar and Andreas (2004) investigated risky driving behaviors in brief surveys of two groups of young California drivers: 1,430 beginning drivers in driver training programs and 880 licensed teenage drivers who were attending traffic school after receiving a moving violation. All drivers recognized that alcohol-impaired driving, sleepiness, speeding, and similar driving behaviors were risky. Drivers who had experienced these behaviors, either through their own 
driving or in a car with another driver, rated them as less risky than those who had not.

Bina, Graziano, and Bonino (in press) studied risky driving and other risky behaviors in a survey of 645 Italian youth aged 14-17. Many of these teenagers drove cars and motorcycles without a proper license, frequently speeding or following too closely. Risky driving was associated with other risky activities, anti-social behavior, smoking, and drug use.

\subsubsection{Personality traits}

Dahlen, Martin, Ragan, and Kuhlman (2005) investigated how driving anger, sensation seeking, impulsiveness, and boredom proneness correlated with aggressive and risky driving in a survey of 224 college students in Mississippi. Driving anger was most predictive, followed by sensation seeking, with modest contributions from impulsiveness and boredom.

Ulleberg and Rundmo (2003) studied how personality affects driving behavior in a survey of 1,932 Norwegian adolescents whose average age was 18.5 years. They concluded that personality traits, such as sensation-seeking and normlessness, affect attitudes toward traffic rules and the enjoyment of driving, which in turn affect driving behavior and risk-taking.

Fernandes and Job (2003) studied how various demographic, personality, and attitudinal factors predict different risky driving behaviors in a survey of 109 Australian university students under 22 years old. They found that different factors predicted different behaviors: for example, authority rebellion predicted speeding while sensation seeking and crash-risk optimism predicted driving after drinking. A survey of 115 older drivers found different predictors.

Sánchez Martín and Estévez (2005) studied 144 young drivers in Spain when they first enrolled in a driving course, at average age 22.5, and again five years later, at which time $40 \%$ reported at least one crash. Cluster analyses produced two quite different cognitive profiles related to crash involvement: one with relatively high practical intelligence, good hand-eye coordination, and good perceptual-motor performance; the other with lower practical intelligence, poor hand-eye coordination, and poor perceptual-motor performance.

\subsubsection{Developmental factors}

In a series of four papers, Bingham and Shope (2004a, $2004 \mathrm{~b}, 2005$, in press) investigated the relationships between various personal and social characteristics of teenagers in their high school years and their subsequent driving behavior. Data for all four studies came from a longitudinal survey of approximately 2,000 Michigan young adults who were contacted in 10th grade, 12 th grade, and at average age of 24 . The first study (2004a) found that selfreported driving under the influence of alcohol or drugs at age 24 was predicted during high school years by alcohol and drug use and by tolerance of social deviance. Selfreported risky driving at age 24 was predicted in high school by alcohol use, tolerance of deviance, less cigarette smoking, and better high school grades. The second paper (2004b) investigated risky driving predictors in more detail. High school students with lower levels of parental monitoring and greater permissiveness, weaker social development, and higher levels of alcohol, drug, and cigarette use were more likely to become risky drivers as young adults.

The third and fourth papers (Bingham and Shope, 2005, in press) investigated how these characteristics in high school predicted crash patterns in the teenage and young adult years as recorded in Michigan driver history records. After adjusting for driving exposure, higher or increasing crash rates were predicted in high school by less parental monitoring, more tolerance for deviance, lower grades, and more substance use.

Taubman-Ben-Ari, Mikulincer, and Gillath (2005) studied associations between driving behaviors of parents and their adult children through a survey of 174 Israeli families. They found significant associations between the driving styles (anxious, reckless, angry, or careful) of parents and children, especially between fathers and sons and between mothers and daughters.

Sagberg and Bjørnskau (2006) investigated whether beginning drivers improve their hazard perception skills during the first few months of driving. There were no significant differences in performance on a video-based hazard perception and reaction test among four groups of drivers who had been licensed for one, five, and nine months and for several years, respectively.

\subsection{Alcohol and drugs}

\subsubsection{Prevalence and trends}

In the 2002 and 2003 U.S. National Surveys on Drug Use and Health (NSDUH) of over 32,000 persons aged 16-20, $21 \%$ reported that they had driven in the past year while under the influence of alcohol (17\%) or drugs (14\%) (SAMHSA, 2004b). The proportion reporting they had driven under the influence of alcohol or drugs rose steadily with age from $10 \%$ of respondents aged 16 to $28 \%$ of those aged 20 .

In the 1999-2001 NSDUH surveys, 10\% of drivers aged 15-17 reported that they had driven in the past year under the influence of alcohol (SAMHSA, 2004a).

In the 2001 Ontario Student Drug Use Survey, 15\% of young drivers in grades 10-13 reported driving within an hour after consuming two or more drinks and $20 \%$ reported driving within an hour after using cannabis (Adlaf, Mann, and Paglia, 2003). The corresponding rates for young drivers in grades 10-12 from the 2002-2003 Student Drug Use Survey in the Atlantic Provinces were 12\% for alcohol and $15 \%$ for cannabis (Asbridge, Poulin, \& Donato, 2005). Both driving after drinking and after using cannabis were correlated with higher crash rates. 


\subsubsection{Attitudes and behavior}

In a 2002 survey of 400 drivers aged $19-25$ in California, $88 \%$ believed it was easy for underage persons to obtain alcohol, $34 \%$ reported that they had driven after drinking, and $17 \%$ after drinking too much to drive safely. More than half believed it was likely they would be stopped by police if they were driving after drinking (University of California Traffic Safety Center, 2003).

McCarthy and Brown (2004) surveyed 2,865 students in four California high schools to investigate how obtaining a drivers license affected drinking behavior. Teens increased their drinking frequency, but not the amount consumed on each drinking occasion, after they received their license, compared to similar-aged teens who were not licensed. Newly licensed drivers also had a higher perception of the dangers of drinking and driving.

Davey, Davey, and Obst (2005) surveyed alcohol and drug attitudes and behavior among 275 university students in Queensland, Australia, of average age 25. Fourteen percent reported that they had driven "under the influence of alcohol" in the past month and $15 \%$ had driven within six hours of drug use in the past year. Attitudes regarding driving after drinking and after using drugs were very similar and generally unfavorable. Peers had a strong influence on attitudes.

Van Beurden, Zask, Brooks, and Dight (2005) studied the relation between binge drinking (defined as six or more drinks at one occasion) and alcohol-impaired driving by surveying students in 40 high schools in New South Wales, Australia. Frequent binge drinkers were more likely to report driving after drinking.

Pinsky, Labouvie, and Laranjeira (2004) surveyed the attitudes regarding drinking and driving of 2,166 young Brazilians aged 18-25 who were about to receive their drivers licenses. Respondents generally did not hold firm attitudes and appeared open both to driving after drinking and to finding other transportation options to avoid driving after drinking.

Sabel, Bensley, and Van Eenwyk (2004) examined associations between self-reported drinking and driving or riding with a drinking driver and other health risk factors in a survey of 2,955 high school students in the state of Washington. Both drinking and driving and riding with a drinking driver were associated with low levels of support from parents and schools and with other risky behaviors such as drinking frequency and quantity, drug use, cigarette smoking, and low safety belt use.

Leung and Starmer (2005) investigated how age and alcohol affect performance on a driving simulator. Sixteen young (19-21) and older (25-35) Australian drivers each were tested at a target blood alcohol content (BAC) of 0.08 and with a no-alcohol placebo. Alcohol at $0.08 \mathrm{BAC}$ affected all drivers' abilities to divide attention but had little effect on their ability to make decisions. In general, the younger drivers drove in a more risky manner and older drivers took longer to detect potential hazards.
Jennifer Zakrajsek and Jean Shope are conducting a longitudinal examination of underage drinking and subsequent risky driving. Young people who begin drinking by middle school subsequently have worse records for driving overall and driving after drinking than those who do not. Results should be available in 2006. For information, contact Jean Shope at jshope@mail.umich.edu.

\subsubsection{Drinking locations}

Walker, Waiters, Grube, and Chen (2005) studied how drinking location affected drinking and driving and riding with a drinking driver through a telephone survey of 1,534 persons aged 15-20 in California. The strongest predictors of both behaviors were heavy drinking and drinking in cars. Drinking in restaurants also predicted drinking and driving. Gender, age, and ethnicity had little effect after controlling for alcohol consumption.

Usdan, Moore, Schumacher, and Talbott (2005) studied drinking locations in a survey of 91 college students identified as being at high risk for drinking and driving. These students had a higher blood alcohol content when driving after drinking at a party than when driving after drinking at other locations.

\subsubsection{Prevention, education, and enforcement programs}

Elder et al. (2005) synthesized studies of high school programs to prevent alcohol-impaired driving. They found evidence of small and inconsistent effects on driving after drinking, small and consistent effects on riding with a drinking driver, and insufficient evidence of effects of either peer organization programs (such as Students Against Destructive Decisions, SADD) or social norming programs.

Carcaillon, Salmi, and Atout-Route Evaluation Group (2005) found a positive but not statistically significant effect for "Atout-Route," an educational program including a contract through which young drivers promise not to drive after drinking, using drugs, or while fatigued. Nelson, Weitzman, and Wechsler (2005) found significant reductions in driving after drinking, driving after five or more drinks, and riding with a drinking driver resulting from "A Matter of Degree," a program directed at a college campus environment that encourages heavy drinking.

Clapp et al. (2005) report the results of a publicized enforcement program to reduce driving after drinking among college students. The program included increased law enforcement through checkpoints and roving patrols coupled with media and social marketing campaigns to increase student perceptions of the risk of arrest. Selfreported driving after drinking decreased significantly after the program among students in the experimental site and remained stable at the comparison site, both of which were large public universities in southwestern United States.

\subsubsection{Drinking and driving laws}

In 1999, New Zealand reduced the minimum alcohol purchase age from 20 to 18. Kypri et al. (2006) compared 
crash data for four years before and two years after the law change. The alcohol-involved crash rate per population increased by $12 \%$ for men aged $18-19$, by $14 \%$ for men aged $16-17$, by $51 \%$ for women aged $18-19$, and by $24 \%$ for women aged $16-17$.

U.S. GDL laws typically do not address driving after drinking because every state has a zero tolerance law that prohibits persons under the age of 21 from driving with a blood alcohol content exceeding 0.02. Carpenter (2004) studied the effects of zero tolerance laws using 1984-2001 Behavioral Risk Factor Surveillance System (BRFSS) data. $\mathrm{He}$ found that these laws reduced binge drinking (five or more drinks at one sitting within the past month) among males age $18-20$ by $13 \%$ compared to males age $22-24$. $\mathrm{He}$ also found a corresponding increase in moderate drinking among males, suggesting that zero tolerance laws may moderate heavy drinking rather than eliminate drinking altogether. Results for females were ambiguous.

\subsection{Speed and other driving behavior}

Whissell and Bigelow (2003) created and validated a 14item speeding attitude scale that had a significant but low correlation with speeding tickets in a sample of 257 undergraduate students in Ontario. Redshaw (2004) reported the views on speeding of young drivers in New South Wales who participated in focus groups. Participants were comfortable with speeding and valued it as a way to save time. They expressed impatience with slow drivers and considered driving at 10 to $20 \mathrm{~km}$ above the speed limit to be normal. They characterized speeding as driving $40 \mathrm{~km}$ or more above the limit.

Two studies compared driving behaviors of 18 newlylicensed teens and 18 experienced adult drivers on a test track. Lee, Olsen, and Simons-Morton (2006) found that the teens had significantly fewer glances to the rearview mirror than the adults during both baseline driving and while performing in-vehicle tasks such as operating a radio or cell phone. Olsen, Simons-Morton, Lee, and Neale (in press) studied behavior when approaching a signalized intersection. The adults were more likely to stop when the traffic light switched from green to amber at each of three distances from the intersection. When approaching the intersection while performing a cell phone task, one-quarter of the teens failed to stop even after the traffic light turned red, while all the adult drivers stopped.

\subsection{In-vehicle distractions}

Simons-Morton, Lerner, and Singer (2005) documented the effects of teenage passengers on young drivers. They observed vehicles leaving parking lots at 10 high schools, recorded the gender and age (teen or adult) of drivers and any passengers, and recorded the vehicle's speed and headway at a nearby site. Teenage drivers drove faster and with shorter headways than general traffic. Drivers with male teenage passengers drove even faster and with shorter headways.
IIHS is reviewing and summarizing the international research literature on the effects of passengers on teenage drivers, especially the effects of teenage passengers. The study should be completed in 2006. For information, contact Susan Ferguson at sferguson@iihs.org.

Driver distraction resulting from cell phone use has been documented extensively. As of 2005, two states, the District of Columbia, and several communities prohibit hand-held cell phone use while driving. Ten states and the District of Columbia prohibit all cell phone use by drivers with a GDL or all drivers under the age of 18 (Governors Highway Safety Association [GHSA], 2005). Strayer and Drews (2004) studied the distracting effects of cell phone conversations in simulated driving. They found similar effects for both younger (age 18-25) and older (age 65-74) drivers. Lerner and Boyd (2005) studied the willingness of 88 drivers to engage in various distracting tasks involving cell phones, personal communication devices, vehicle navigation systems, passengers, and food. The 22 teenagers perceived the tasks as less risky and were more willing to engage in them than older drivers.

\subsection{Drowsy driving}

It is well-documented that drowsy driving (driving while sleepy or fatigued) causes crashes and also that many young persons do not get enough sleep. Two studies explored the role of sleep for young drivers. Carskadon (2002) reported on two surveys of several hundred high school and college students. Two-thirds of the drivers in one survey reported having driven while sleepy, and onefifth in the other reported they had fallen asleep while driving. The students believed that driving while sleepy is less risky than driving while impaired by alcohol. Smith, Carrington, and Trinder (2005) investigated the relationship between predicted and perceived sleepiness while driving in 47 young persons aged 18-25 over four weeks. Participants often drove when they perceived themselves to be sleepy. Many of these trips were at times when sleepiness could be predicted because the driver had been awake for a long period.

\subsection{Medical conditions}

Barkley (2004) provides an overview of the how attention-deficit or hyperactivity disorder (ADHD) can affect driving, among younger and older drivers alike, and suggests potential strategies to control its effects.

\subsection{Vehicles driven}

Kindelberger and Eigen (2003) documented crash characteristics for young drivers of sport utility vehicles (SUVs). From 1992 through 2001, about one-quarter of all SUVs in crashes had drivers aged 16-24. These young drivers were substantially more likely to roll their SUV 
over in a crash than older drivers, especially if the young drivers were in older SUVs.

Williams, Leaf, Simons-Morton, and Hartos (2006) studied vehicle access and ownership of 3,743 Connecticut teenagers in their first year of licensure. More than half of both male and female teens owned a vehicle when they were first licensed and almost all had regular access to a vehicle. A year later, $74 \%$ owned a vehicle. About half of the teens drove small passenger cars and about one-quarter drove SUVs, pickups, or sports cars. At licensure, teens who owned vehicles reported that they averaged 90 miles of weekly driving and teens who did not own vehicles reported an average of 51 miles. Leaf, Simons-Morton, Hartos, and Northrup (2005) investigated the accuracy of these mileage estimates using a subsample of 118 teens. The teens' simple report of their total mileage for the week was $20-30 \%$ lower than estimates obtained by asking about each trip throughout the week or from trip logs.

Yannis, Golias, and Papadimitriou (2005) investigated the combined effects of driver age and engine size on motorcycle crashes in Greece. Once the interaction of driver age on accident fault was taken into account, engine size had no effect.

\subsection{High school policies}

McCartt, Geary, and Solomon (2005) studied the effects of a high school policy requiring safety belt use for everyone in the cars of student drivers with parking permits. Few of the 38 schools contacted for the study were interested in adopting such a policy. Driver belt use, measured at the school, increased from $42 \%$ to $67 \%$ after the policy was implemented in one school in Mississippi, a state with a secondary belt use law and generally low rates. Passenger belt use increased from $16 \%$ to $61 \%$. The policy had no effect in one school in Connecticut, where $86 \%$ of drivers and $79 \%$ of passengers were belted before the policy.

Stone and Runyan (2005) studied the effect on crash rates of high school policies allowing students to drive off campus during lunchtime. They found significantly higher crash rates for teenagers during lunch hours in two North Carolina counties with these open-lunch policies compared to one county in which students remained on campus.

HSRC is completing a study of the effect of high school starting times on teenage driver crash rates. Preliminary results suggest that moving very early morning (7:30 a.m. or earlier) starting times later by an hour or more may reduce weekday crashes during the school year by $10 \%$. HSRC plans more extensive work on this issue. For information, contact Rob Foss at foss@hsrc.unc.edu.

\section{Effectiveness of GDL as implemented}

Two new state-level evaluations and two multi-jurisdictional studies add to the evidence that GDL reduces teenage crashes and injuries. Several other evaluations should be released in 2006.

\subsection{Wisconsin}

In September 2000, Wisconsin implemented a GDL law that extended the minimum learner's permit holding period to six months from seven days, required at least 30 hours of supervised practice driving, and added a 9-month intermediate stage with nighttime and passenger restrictions. Fohr, Layde, and Guse (2005) evaluated the law's effects. The per-population crash rate for 16-year-old drivers decreased $14 \%$ from 1999 to 2003 compared to the crash rate for drivers aged 25-59, and the injury crash rate decreased $16 \%$. For 17 -year-old drivers, both the overall and the injury crash rates decreased $6 \%$; for 18 -year-old drivers there was a small but not statistically significant decrease in both crash rates. There were substantially fewer crash-involved 16year-old drivers carrying two or more teenage passengers in 2002 compared to 1999. There were very few crashes during the restricted hours of midnight to $5 \mathrm{a}$.m. in both years. There was no statistically significant change in the odds of a 16-or 17-year-old driver being at fault in a crash. From this latter result, the authors concluded that GDL's effect was due to reduced teenage driving through delayed licensure and reduced driving in risky situations through the intermediate license restrictions rather than to safer driving by teens.

McIntosh (2005) reported on knowledge and attitude surveys administered to 26 parent-teen pairs in the Madison, Wisconsin area in 2002 and 2003. Both parents and teens knew the GDL requirements very well. While $76 \%$ of parents supported the law, $70 \%$ of teens opposed it.

\subsection{Texas}

On January 1, 2002, Texas implemented a GDL law with a 6-month learner's permit holding period and a 6-month intermediate stage with nighttime (midnight to 5 a.m.) and passenger (no more than one under the age of 21) restrictions. Willis (2005) used FARS data to compare fatal crashes involving at least one 16-year-old driver during twoyear periods before and after the law. The number of 16year-olds who held a drivers license dropped from $43 \%$ in 2000 to $28 \%$ in 2003 , a decrease of $34 \%$. Fatal crashes involving 16-year-old drivers dropped 29\%, from 103 in 2000 to 76 in 2003 . The fatal crash involvement rate per licensed driver rose slightly. Crash circumstances, including time of day and number of passengers, were quite similar for the pre-and post-GDL fatal crashes. FARS data do not contain the date of licensure so cannot determine which of the post-GDL 16-year-old drivers were subject to the nighttime and passenger restrictions. Henk and Fette (2006) provide some evidence that these restrictions may not be well understood. In surveys of about 2,000 students 
in two Texas high schools in both October 2002 and April 2003 , one-third of the students were "not at all familiar" with GDL requirements and only one-sixth were "very familiar" with them.

\subsection{Multi-jurisdiction studies and summaries}

Dee, Grabowski, and Morrisey (2005) studied GDL effects on fatalities in a cross-section analysis using 19922002 FARS data from 48 states (excluding Alaska, Hawaii, and the District of Columbia) and controlling for other influences on teen drivers. They concluded that GDL, defined as any system with an intermediate licensing phase, reduced traffic fatalities among teenagers aged $15-17$ by at least $5.6 \%$ and did not increase fatalities among older teens.

Morrisey, Grabowski, Dee, and Campbell (2006) carried these methods further and compared the effects of GDL programs of different strengths, as defined by IIHS and TIRF (2004). They concluded that "good" programs reduced traffic fatalities among drivers aged 15-17 by $19 \%$. "Fair" programs reduced nighttime fatalities by $13 \%$ but had no effect on daytime fatalities. "Marginal" programs had no effect.

Mayhew et al. (2005) summarized five GDL evaluations in Canada and 13 in the United States, including tables comparing the crash reductions achieved in different jurisdictions.

McKnight (2006) summarized the history and previous evaluations of Maryland's GDL, from its initial implementation in 1978 through revisions in 1985, 1998, and 2005.

Hartling and colleagues plan to update their Cochrane GDL review in late 2006 or 2007. For information, contact Lisa Hartling at lisa.hartling@ualberta.ca.

\subsection{GDL evaluations in progress}

California: PRG is re-analyzing California data to understand and reconcile the conflicting results of three recent California evaluations summarized in Hedlund and Compton (2005). The study, sponsored by IIHS, should be released in early 2006. For information, contact Susan Ferguson at sferguson@iihs.org.

Georgia: Emory University's study, funded by the National Highway Traffic Safety Administration (NHTSA), should be released in early 2006. For information, contact Paul Tremont at Paul.Tremont@nhtsa.dot.gov.

North Carolina: The University of North Carolina School of Public Health and HSRC studied the effect of North Carolina's GDL system on hospitalization rates and hospital charges for 16-year-old drivers. Preliminary results suggest that hospitalization rates and charges have decreased similarly to the previously-reported decrease in crash rates. Funded by CDC and State Farm Insurance, the study should be released in early 2006. For information, contact Lewis Margolis at lmargoli@email.unc.edu. HSRC is examining three other GDL questions using North
Carolina data: long-term effects of GDL, the effects of a passenger restriction, and whether GDL has produced crash reductions beyond those attributable to reduced or delayed licensure. For information, contact Rob Foss at foss@hsrc. unc.edu.

Ontario: TIRF's evaluation is under final review by the sponsor, the Ontario Ministry of Transportation. For information, contact Dean Morin at deanm@trafficinjuryresearch. com.

Oregon: The NHTSA-sponsored study by the Center for Applied Research should be released in 2006. For information, contact Patricia Ellison-Potter at Patricia.Ellison-Potter@ nhtsa.dot.gov.

Quebec: The Société de l'Assurance Automobile's evaluation should be released in 2006. For information contact Robert Simard at Robert.Simard@saaq.gouv.qc.ca.

United States: Johns Hopkins University, in a NHTSAsponsored study, is evaluating GDL and its components nationwide using national crash databases. The study should be released in 2006. For information, contact Paul Tremont atPaul.Tremont@nhtsa.dot.gov.

United States: Johns Hopkins is conducting a second national study for the AAA Foundation for Traffic Safety (AAAFTS). The study will examine licensing rates and mileage driven to separate GDL's effects on driving behavior and driving exposure. The study also will provide more information on the effects of individual GDL components. The study should be completed in 2006. For information, contact Scott Osberg at sosberg@ aaafoundation.org.

Mayhew and colleagues at TIRF are comparing young drivers' crash characteristics, conditions, and circumstances in two jurisdictions with substantially different GDL programs. A second study examines how a wide range of young drivers' attitudes, motivations, and lifestyle variables relate to crash involvement, again in two jurisdictions with quite different GDL programs. A report on both studies, funded by AAAFTS, should be released in 2006. For information, contact Scott Osberg at sosberg@ aaafoundation.org.

\section{Operational features of GDL for parents and teens}

Begg and colleagues in New Zealand will begin a large prospective cohort study in 2006. The study, described in last year's update (Hedlund and Compton, 2005), will follow beginning drivers as they progress through the learner's permit, intermediate, and full licensure stages. For information, contact Dorothy Begg at dorothy.begg@ ipru.otago.ac.nz.

\subsection{GDL acceptance}

In 1998, California extended the learner's permit holding period from one to six months, required at least 50 hours of 
supervised practice, and introduced nighttime and passenger restrictions during the intermediate phase. Williams, Nelson, and Leaf (2002) surveyed parents and teens on their reactions to and compliance with the new requirements. Parents whose children were subject to the new GDL requirements supported them, with $79 \%$ strongly in favor and only $4 \%$ neutral or opposed. Over $80 \%$ of teenagers supported the extended learner's permit period and the 50hour practice requirement and over $60 \%$ supported the nighttime driving restriction, but fewer than half supported the passenger restriction. Teens reported that they generally obeyed the nighttime restriction: $58 \%$ said they never drove after midnight in their first six months with an intermediate license, and another $27 \%$ drove 1-9 times. Compliance with the prohibition on passengers under the age of 20 was lower: only $20 \%$ reported complete compliance, while $60 \%$ violated the restriction at least 10 times (and 36\% violated it at least weekly).

Blows, Ivers, and Chapman (2005) analyzed Australian print media coverage of proposals for nighttime and passenger restrictions. Fifty-two articles were published in a 12-week period, including news stories, opinion articles, editorials, and letters. The authors identified about 15 common arguments each from proponents and opponents and described how these arguments are positioned, or framed, into broader contexts such as individual values, problem significance, research evidence, and practicality.

\subsection{GDL enforcement}

Goodwin, Wells, Foss, and Williams (2005) studied the effects of well-publicized enforcement of GDL provisions, including nighttime and passenger restrictions and a safety belt use requirement, in one North Carolina county $(400,000$ population), with another county used as a comparison site. In addition to regular patrols, enforcement activities included checkpoints near high schools when students were dismissed and nighttime saturation patrols in locations popular among teenage drivers. Teenagers were aware of the increased enforcement. But both self-reported data and direct observations of young drivers showed only modest changes in compliance with GDL provisions.

A CDC-funded follow-up study is underway to test similar enforcement and publicity activities in other settings. For information, contact Arthur Goodwin at arthur_goodwin@ unc.edu.

\subsection{Parental roles and programs to assist parents and teens}

Hartos, Simons-Morton, Beck, and Leaf (2005) studied whether GDL helps parents manage their beginning drivers by comparing survey results from Maryland, a GDL state, and Connecticut, a state without GDL. Maryland parents imposed stricter restrictions than Connecticut parents regarding teenage passengers, nighttime driving, and highspeed road driving.
Simons-Morton and colleagues provided additional evidence that the Checkpoints program helps parents manage their teens' driving (Simons-Morton, Hartos, Leaf, \& Preusser, 2005, 2006a, 2006b). They surveyed parents and teens before licensure and at 3, 6, and 12 months post-licensure. Checkpoints program parents and teens reported substantially stricter limits than comparison parents and teens through 3 months, and some effects through 12 months. A follow-up study is comparing the effectiveness of the Checkpoints program when delivered at the time of issuing the learner's permit or the intermediate license, assessing the effectiveness of communications on risk factors for parents and teens, and assessing the effectiveness of the Checkpoints parent-teen driving agreement. For information, contact Bruce Simons-Morton at mortonb@exchange.nih.gov.

In a series of papers, Beck, Hartos, and Simons-Morton (2005, in press-a, in press-b) are reporting the results of their studies of how agreement between parents and teens on parent-imposed driving restrictions affects teens' driving behavior.

Shope and colleagues at UMTRI, with funding from the National Institute of Child Health and Human Development and $\mathrm{CDC}$, are implementing and evaluating an adapted version of the Checkpoints program in driver education classes in Michigan. Results should be available in 2006. For information, contact Jean Shope at jshope@umich.edu.

Hartos is studying the transition from parent-imposed to self-regulated safe driving practices among undergraduates at the University of North Carolina, Charlotte. For information, contact Jessica Hartos at jhartos@email.uncc.edu.

Three programs to assist parents and beginning drivers have been released recently.

- Driving Skills for Life, developed by Ford and GHSA, emphasizes four skills: hazard recognition, vehicle handling, space management, and speed management (Ford and GHSA, 2003). The program's educational kit includes a video, teacher's guide, and brochure and the Web site contains on-line learning materials and parental tips and coaching guide. It has been sent to every public high school in the United States and the materials have reached an estimated 4 million teenagers and their parents.

- Road Ready Teens, developed by DaimlerChrysler together with AAA, MADD, and the National Safety Council, provides a parent's guide, a parent-teen contract, and a video game and Road Ready Reality Check quiz for teens (DaimlerChrysler, 2003). Bingham and Shope (2003) conducted a pilot evaluation of the video game using 19 teens, most of whom held learners permits. The teens played the game for 50 minutes and then participated in a focus group. The teens enjoyed the game and reported that it helped them understand driving risks but the game did not produce significant changes in their intentions to avoid risks. 
- Teen Driver: A Family Guide to Teen Driver Safety, developed by the National Safety Council, provides information and advice to parents and teens on crash risks, how to develop a family plan and written agreement for beginning drivers, and GDL components and restrictions (National Safety Council [NSC], 2004). The University of North Carolina at Charlotte will evaluate the content and use of the Guide, strategies to implement it into new and existing driver safety programs, and how it helps families manage their teens' driving. For information on the CDC-funded project, contact Jessica Hartos at jhartos@email.uncc.edu.

The Allstate Foundation is developing a teenage driver safety program featuring teen participation and grassroots empowerment. The report announcing the program (Allstate Foundation, 2005) contains results from a national electronic survey of 1,000 teens on their driving attitudes and behavior and also discusses the implications on teenage driving of recent research on adolescent brain development.

Votta and MacKay (2005) studied an experimental family program, I Promise, consisting of a contract between parents and teen drivers and a window decal. Focus groups of young drivers, parents, and community members revealed substantial difficulties with the program's message, content, and language. Most families chose not to continue with the program after a pilot phase.

Henk and Fette (2006) studied the effects of a pilot program in high schools using a peer-to-peer approach to increase awareness among teenage drivers of common risk factors such as speeding, teenage passengers, and driving at night. Student awareness of several risk factors increased in the pilot high school, while there was no consistent change in the comparison school. The program is being refined and expanded to other Texas high schools. For information, contact Russell Henk at r-henk@tamu.edu.

\section{Driver education and GDL}

Research continues on the relationship between driver education and GDL and how to integrate them effectively.

\subsection{Overviews}

Bishop, Quinlan, Roeber, and Van Etten (2005) summarized the proceedings of the 2003 National Transportation Safety Board (NTSB) public forum on driver education and training. They provided brief histories of driver education and GDL in the United States. They summarized the views of forum participants from federal and state governments, driver education teachers, students, associations, and private companies. In August 2005, NTSB recommended that NHTSA and the United States Department of Education determine the best driver education curricula, training methods, and instructional tools; incorporate these into a model curriculum; and determine how driver education should best be integrated with GDL (NTSB, 2005).

"Driver Education: The Path Ahead" was the subject of the 2005 midyear meeting of the Transportation Research Board (TRB) Operator Education and Regulation committee (ANB30). Papers written for the meeting discuss driver education content, instructional methods, student competency measures, and course evaluation. The papers will be published in 2006 as a TRB Circular, edited by Daniel Mayhew and James McKnight.

Lonero and Clinton (submitted for publication) of Northport Associates are completing a thorough review of the driver education evaluation literature that identifies and assesses evaluation methods and data sources and provides recommendations. The report, funded by AAAFTS, is scheduled for release in 2006. For information, contact Scott Osberg at sosberg@aaafounation.org.

\subsection{Driver education and crash risk}

Zhao et al. (2006) investigated the impact of driver education on crash risk in the context of Ontario's GDL system. In Ontario, the minimum learner's permit holding period is reduced from 12 to 8 months for driver education graduates. Using self-report survey data from beginning drivers, and controlling for both months of licensure and kilometers of travel, the authors found that driver education reduced crash risk during the learner's permit phase and did not affect crash risk during the intermediate phase.

Maag and colleagues at the Université de Montréal have completed their comparison of crash rates for intermediate license drivers who have and have not taken driver education. The study may be obtained from Robert Simard at Robert.Simard@saaq.gouv.qc.ca.

\section{Other related research}

\subsection{GDL for motorcyclists}

A few jurisdictions use some form of GDL for beginning motorcyclists. Several other states place some restrictions on motorcyclists with a learner's permit or those younger than a specified age. Mayhew and Simpson (2001) described GDL programs in Canada, California, Maryland, and South Dakota and summarized the effectiveness evidence from motorcycle GDL programs in Quebec and New Zealand. Baer, Cook, and Baldi (2005) reported that seven states had some form of GDL for motorcyclists in 2001. See Motorcycle Safety Foundation [MSF] (2002) for state motorcycle operator requirements and restrictions.

\subsection{In-vehicle technology}

Several in-vehicle technology systems that may reduce the frequency or severity of young drivers' crashes are being 
tested or are currently available. Young, Regan, and Mitsopoulos (2004) used focus groups of young drivers aged 17-25 to evaluate the acceptability of these systems. The systems studied were warnings for driver fatigue, lane departure, following distance, and collision; speed monitoring that either warns of or limits excessive speed; alcohol interlocks and alcohol performance tests; safety belt reminders or interlocks; and electronic licensing. Acceptability was evaluated by considering each system's usefulness, effectiveness, usability, cost, and social acceptability. The only well-accepted systems were alcohol interlocks and safety belt reminders, and focus group drivers believed belt use reminders were unnecessary. The paper provides references to a few other studies of vehicle technology acceptability.

\subsection{Simulator studies}

TraumaLink Injury Research Center at The Children's Hospital of Philadelphia, in cooperation with the University of Iowa, is studying the usefulness of the National Advanced Driving Simulator for teen driver research. The NSF-funded project will examine on-road and simulated driving for teens and compare their performance to other age groups. The performance of high and low sensation seeking teens will also be explored while controlling for driving experience. Other TraumaLink projects are investigating the driving exposure of young drivers with teenage passengers and with child passengers, unlicensed and underage driving, and teen perceptions of driving risks, other health risk behaviors, and associated interventions. For information, contact Suzanne Hill at hillsu@email.chop.edu.

\subsection{Teen driving newsletter}

Erik Olsen at the National Institute of Child Health and Human Development, in cooperation with the TRB Operator Education and Regulation Committee, has started a teen driving email newsletter to report on ongoing and published research, conferences, and resources regarding teen drivers. The first issue may be found at http:// www.teendrivinginfo.com/teen_driving_newsletter.htm.

\section{Conclusions and next steps}

Research on teenage driving issues in general and GDL in particular continues to grow. The 2004 and 2005 updates cited 37 and 52 new papers, respectively; this update cites 107. To assess what has been learned from this research and from recent experience with young driver programs, a symposium on teenage driving is planned for February 2007. The 2007 symposium and background papers will summarize the current state of knowledge on key GDL and teenage driver issues, including the role of parents, driver education, and new technology, and will discuss research needs and action steps. For information on the symposium, contact Deborah Trombley of the National Safety Council at trombled@nsc.org. Readers are invited to send new and recent studies not included in any of the updates to Jim Hedlund at jhedlund@sprynet.com, who will pass them on to the 2007 symposium's organizers and background paper authors.

\section{Acknowledgments}

This study was supported by the Centers for Disease Control and Prevention. The opinions, findings, and conclusions are those of the authors and do not necessarily represent the views of the Centers for Disease Control and Prevention or the National Highway Traffic Safety Administration.

The authors thank Christy Cechman for conducting the literature search and Susan Ferguson, Rob Foss, Daniel Mayhew, Jean Shope, and Allan Williams for reviewing drafts and providing valuable advice.

\section{References}

AAA. (2006). Teen crashes - everyone is at risk. Washington, DC: Author. Adams, C. (2005). Probationary and non-probationary drivers' nighttime crashes in Western Australia, 1996-2000. Journal of Safety Research, 36(1), 33-37.

Adlaf, E. M., Mann, R. E., \& Paglia, A. (1999). Drinking, cannabis use and driving among Ontario students. Canadian Medical Association Journal, 168(5), 565-566.

Allstate Foundation. (2005). Chronic: A report on the state of teen driving 2005. Northbrook, IL: Author.

Asbridge, M., Poulin, C., \& Donato, A. (2005). Motor vehicle collision risk and driving under the influence of cannabis: Evidence from adolescents in Atlantic Canada. Accident Analysis and Prevention, 37(6), $1025-1034$.

Aultman-Hall, L., \& Padlo, P. (2004). Factors affecting young driver safety. Storrs, CT: University of Connecticut Transportation Institute.

Baer, J. D., Cook, A. L., \& Baldi, S. (2005). Motorcycle rider education and licensing: A review of programs and practices. DOT HS 809852. Washington, DC: U.S. Department of Transportation.

Barkley, R. A. (2004). Driving impairments in teens and adults with attention-deficit/hyperactivity disorder. Psychiatric Clinics of North America, 27(2), 233-260.

Beck, K. H., Hartos, J. L., \& Simons-Morton, B. G. (2005). Parent-teen disagreement of parent-imposed restrictions on teen driving after 1month of licensure: Is discordance related to risky teen driving? Prevention Science, 6(3), 177-185.

Beck, K. H., Hartos, J. L., \& Simons-Morton, B. G. (in press-a). Parent-teen concordance of driving rules, restrictions and consequences: Is concordance related to risky driving after licensure? Health Education and Behavior.

Beck, K. H., Hartos, J. L., \& Simons-Morton, B. G. (in press-b). The relation of parent-teen agreement on driving restrictions and teen risky driving: Results of a 9-month follow-up. American Journal of Health Behavior.

Bellavance, F., Bellavigna-Ladoux, O., Dassa, C., Gou, M., LabergeNadeau, C., Messier, S., \& Thiffault, P. (2005). Les Nouveaux Conducteurs: Profil, Prise de Risque, Évaluation des Compétences et Tests. Montreal, QC: Université de Montréal.

Bina, M., Graziano, F., \& Bonino, S. (in press). Risky driving and lifestyles in adolescence. Accident Analysis and Prevention, 38. 
Bingham, C. R., \& Shope, J. T. (2003). An Evaluation of the Road Ready Teens Video Game: Final Report (Publication 2003-28). Ann Arbor, MI: University of Michigan Transportation Research Institute.

Bingham, C. R., \& Shope, J. T. (2004). Adolescent problem behavior and problem driving in young adulthood. Journal of Adolescent Research, 19(2), 205-223.

Bingham, C. R., \& Shope, J. T. (2004). Adolescent developmental antecedents of risky driving among young adults. Journal of Studies on Alcohol, 65(1), 84-94.

Bingham, C. R., \& Shope, J. T. (2005). Adolescent predictors of traffic crash patterns from licensure into early young adulthood. Proceedings of the Association for Advancement of Automotive Medicine, 49, $245-259$.

Bingham, C. R., \& Shope, J. T. (in press). Patterns of traffic offenses from adolescent licensure into early young adulthood. Journal of Adolescent Health.

Bishop, J., Quinlan, K., Roeber, D., \& Van Etten, G. (2005). Driver education and training forum. Journal of Accident Investigation, 1(1), $36-43$.

Blows, S., Ivers, R. Q., \& Chapman, S. (2005). "Banned from the streets I have paid to use": an analysis of Australian print media coverage of proposals for passenger and night driving restrictions for young drivers. Injury Prevention, 11(5), 304-308.

Carcaillon, L. I., \& Salmi, L. R., \& Atout-Route Evaluation Group. (2005). Evaluation of a program to reduce motor-vehicle collisions among young adults in the county of Landes, France. Accident Analysis and Prevention, 37(6), 1049-1055.

Carpenter, C. (2004). How do zero tolerance drunk driving laws work? Journal of Health Economics, 23(1), 61-83.

Carskadon, M. A. (2002). Risks of driving while sleepy in adolescents and young adults. In M. A. Carskadon (Ed.), Adolescent sleep patterns. New York, NY: Cambridge University Press.

Clapp, J. D., Johnson, M., Voas, R. B., Lange, J. E., Shillington, A., \& Russell, C. (2005). Reducing DUI among US college students: results of an environmental prevention trial. Addiction, 100(3), $327-334$

Clarke, D. D., Ward, P., \& Truman, W. (2005). Voluntary risk taking and skill deficits in young driver accidents in the UK. Accident Analysis and Prevention, 37(3), 523-529.

Dahlen, E. R., Martin, R. C., Ragan, K., \& Kuhlman, M. M. (2005). Driving anger, sensation seeking, impulsiveness, and boredom proneness in the prediction of unsafe driving. Accident Analysis and Prevention, 37(2), 341-348.

DaimlerChrysler. (2003). Road Ready Teens. Auburn Hills, MI: Author http://www.roadreadyteens.org/index.html

Davey, J. D., Davey, T., \& Obst, P. L. (2005). Drug and drink driving by university students: An exploration of the influence of attitudes. Traffic Injury Prevention, 6(1), 44-52.

Dee, T. S., Grabowski, D. C., \& Morrisey, M. A. (2005). Graduated driver licensing and teen traffic fatalities. Journal of Health Economics, 24(3), $571-589$.

Elder, R. W., Nichols, J. L., Shults, R. A., Sleet, D. A., Barrios, L. C., Compton, R., \& Task Force on Community Preventive Services. (2005). Effectiveness of school-based programs for reducing drinking and driving and riding with drinking drivers: A systematic review. American Journal of Preventive Medicine, 28(5, Supplement), 288-304.

Elliott, M. E., Shope, J. T., Raghunathan, T. E., \& Waller, P. F. (2006). Gender differences in the association between high-risk driving and alcohol and substance use/environmental influences. Journal of Studies on Alcohol, 67(2), 252-260.

Fernandes, R., \& Job, R. F. S. (2003). Different factors predict different risky driving behaviours: a challenge to the assumed generalizability of prediction and countermeasure. Sydney, Australia: Proceedings of 2003 Road Safety Research Policing and Education Conference.

Fohr, S. A., Layde, P. M., \& Guse, C. E. (2005). Graduated driver licensing in Wisconsin: does it create safer drivers? Wisconsin Medical Journal, 104(7), 31-36.
Ford and Governors Highway Safety Association [GHSA]. (2003). Driving Skills for Life. Dearborn, MI: Ford Motor Company http://www. drivingskillsforlife.com/

Gonzales, M. M., Dickinson, L. M., DiGuiseppi, C., \& Lowenstein, S. R. (2005). Student drivers: a study of fatal motor vehicle crashes involving 16-year-old drivers. Annals of Emergency Medicine, 45(2), 140-146.

Goodwin, A. H., Wells, J. K., Foss, R. D., \& Williams, A. F. (2005). Encouraging compliance with graduated driver licensing restrictions. Washington, DC: Insurance Institute for Highway Safety.

Governors Highway Safety Association [GHSA]. (2005). Cell phone restrictions - state and local jurisdictions. Washington, DC: Author.

Harré, N., Foster, S., \& O’Neill, M. (2005). Self-enhancement, crash-risk optimism and the impact of safety advertisements on young drivers. British Journal of Psychology, 96(2), 215-230.

Hartos, J. L., Simons-Morton, B. G., Beck, K. H., \& Leaf, W. A. (2005). Parent-imposed limits on high-risk adolescent driving: are they stricter with graduated driver licensing? Accident Analysis and Prevention, $37(3), 557-562$.

Hasselberg, J., \& Laflamme, L. (2005). The social patterning of injury repetitions among young car drivers in Sweden. Accident Analysis and Prevention, 37(1), 163-168.

Hedlund, J., \& Compton, R. (2004). Graduated driver licensing research in 2003 and beyond. Journal of Safety Research, 35(1), 5-11.

Hedlund, J., \& Compton, R. (2005). Graduated driver licensing research in 2004 and 2005. Journal of Safety Research, 36(2), 109-119.

Hedlund, J., Shults, R. A., \& Compton, R. (2003). What we know, what we don't know, and what we need to know about graduated driver licensing. Journal of Safety Research, 34(1), 107-115.

Henk, R. H., \& Fette, B. (2006). Teens in the driver seat: Results of a peerto-peer pilot project in Texas. TRB Annual Meeting CD-ROM. Washington, DC: Transportation Research Board.

Insurance Institute for Highway Safety [IIHS]. (2005). U.S. licensing systems for young drivers. Arlington, VA: Insurance Institute for Highway Safety Available at: www.highwaysafety.org/laws/state_laws/ pdf/us_licensing_systems.pdf

IIHS \& TIRF. (2004). Graduated licensing: a blueprint for North America. Arlington, VA: Insurance Institute for Highway Safety Available at: www.highwaysafety.org

Kindelberger, J., \& Eigen, A. M. (2003). Younger drivers and sport utility vehicles. HS-809-636. Washington, DC: U.S. Department of Transportation.

Kypri, K., Voas, R. B., Langley, J. D., Stephenson, S. C., Begg, D. J., Tippetts, A. S., \& Davie, G. S. (2006). Traffic crash injuries among 15-to 19-year-olds and minimum purchasing age for alcohol in New Zealand. American Journal of Public Health, 96(1), 126-131.

Laflamme, L., Vaez, M., Hasselberg, M., \& Kullgren, A. (2005). Car safety and social differences in traffic injuries among young adult drivers: a study of two-car injury-generating crashes in Sweden. Safety Science, $43(1), 1-10$

Leaf, W. A., Simons-Morton, B. G., Hartos, J. L., \& Northrup, V. S. (2005). Driving miles estimates by teen drivers: How accurate are they? Trumbull, CT: Preusser Research Group.

Lee, S. E., Olsen, E. C. B., \& Simons-Morton, B. G. (2006). Eye glance behavior of novice teen and experienced adult drivers. TRB Annual Meeting CD-ROM. Washington, DC: Transportation Research Board.

Lerner, N., \& Boyd, B. (2005). On-Road Study of Willingness to Engage in Distracting Tasks. DOT HS 809 863. Washington, DC: U.S Department of Transportation.

Leung, S., \& Starmer, G. (2005). Gap acceptance and risk-taking by young and mature drivers, both sober and alcohol-intoxicated, in a simulated driving task. Accident Analysis and Prevention, 37(6), $1056-1065$.

Lonero, L., \& Clinton, K. (submittted for publication). Guidelines for Evaluating Driver Education Programs. Washington, DC: AAA Foundation for Traffic Safety.

Mayhew, D. R., \& Simpson, H. M. (2001). Graduated licensing for motorcyclists. Ottawa, ON: Traffic Injury Research Foundation. 
Mayhew, D. R., Simpson, H. M., \& Singhal, D. (2005). Best practices for graduated driver licensing in Canada. Ottawa, ON: Traffic Injury Research Foundation.

McCarthy, D. M., \& Brown, S. A. (2004). Changes in alcohol involvement, cognition and drinking and driving behavior for youth after they obtain a driver's license. Journal of Studies on Alcohol, 65(3), 289-296.

McCartt, A. T., Geary, L. L., \& Solomon, M. G. (2005). Requiring belt use as part of a school parking permit program: Does it increase students' belt use? Traffic Injury Prevention, 6(2), 120-126.

McIntosh, G. (2005). Wisconsin's experience with the graduated driver licensing law. Wisconsin Medical Journal, 104(1), 52-56.

McKay, M. P. (2005). Commentary: novice teen drivers and crashes-just how worried should we be and what should we do about it? Annals of Emergency Medicine, 45(6), 639-642.

McKnight, A. J. (2006). Maryland graduated licensing. Calverton, MD: Pacific Institute for Research and Evaluation.

Morrisey, M. A., Grabowski, D. C., Dee, T. S., \& Campbell, C. (2006). The strength of graduated driver's license programs and fatalities among teen drivers and passengers. Accident Analysis and Prevention, 38(1), 135-141.

Motorcycle Safety Foundation [MSF]. (2002). State Motorcycle Operator Licensing - 2002. Irvine, CA: Author.

National Committee on Uniform Traffic Laws and Ordinances [NCUTLO]. (2002). Graduated driver licensing model law. Alexandria, VA: Author www.ncutlo.org/gradlaw2.html

National Safety Council [NSC]. (2004). Teen Driver: A Family Guide to Teen Driver Safety. Itasca, IL: Author http://www.nsc.org/issues/teendriving/guide.htm

National Transportation Safety Board [NTSB]. (2005). Safety Recommendations H-05-25 and-26. Washington, DC: Author.

Nelson, T. F., Weitzman, E. R., \& Wechsler, H. (2005). The effect of a campus-community environmental alcohol prevention initiative on student drinking and driving: Results from the "A Matter of Degree" program. Traffic Injury Prevention, 6(4), 323-330.

Olsen, E. C. B., Simons-Morton, B. G., Lee, S. E., \& Neale, V. L. (in press). Intersection behavior of novice teen drivers and experienced adult drivers. Human Factors.

O’Malley, P. M., \& Johnston, L. D. (2003). Unsafe driving by high school seniors: national trends from 1976 to 2001 in tickets and accidents after use of alcohol, marijuana and other illegal drugs. Journal of Studies on Alcohol, 64(3), 305-312.

Paschall, M. J. (2003). College attendance and risk-related driving behavior in a national sample of young adults. Journal of Studies on Alcohol, 64(1), 43-49.

Pinsky, I., Labouvie, E., \& Laranjeira, R. (2004). Willingness and alternatives to drunk driving among young people from Sao Paulo City, Brazil. Revista Brasileira Psiquiatria, 26(4), 234-241.

Redshaw, S. (2004). Young people's ideas on speed. Road and Transport Research, 13(4), 51-62.

Rhodes, N., Brown, D., \& Edison, A. (2005). Approaches to understanding young driver risk taking. Journal of Safety Research, 36(5), 497-499.

Sabel, J. C., Bensley, L. S., \& Van Eenwyk, J. (2004). Associations between adolescent drinking and driving involvement and self-reported risk and protective factors in students in public schools in Washington state. Journal of Studies on Alcohol, 65(2), 213-216.

Sagberg, F., \& Bjørnskau, T. (2006). Hazard perception and driving experience among novice drivers. Accident Analysis and Prevention, $38(2), 407-414$.

SAMHSA. (2004a). Graduated driver licensing and drinking among young drivers. The NSDUH Report, April 30, 2004.

SAMHSA. (2004b). Driving under the influence (DUI) among young persons. The NSDUH Report, December 31, 2004

Sánchez Martín, F., \& Estévez, Á. Q. (2005). Prevention of traffic accidents: The assessment of perceptual-motor alterations before obtaining a driving license. A longitudinal study of the first years of driving. Brain Injury, 19(3), 189-196.
Sarkar, S., \& Andreas, M. (2004). Acceptance of and engagement in risky driving behaviors by teenagers. Adolescence, 39(156), 687-700.

Senserrick, T., \& Haworth, N. (2005). Review of literature regarding national and international young driver training, licensing and regulatory systems. Victoria, Australia: Monash University Accident Research Centre.

Simons-Morton, B., Lerner, N., \& Singer, J. (2005). The observed effects of teenage passengers on the risky driving behavior of teenage drivers. Accident Analysis and Prevention, 37(6), 973-982.

Simons-Morton, B. G., Hartos, J. L., Leaf, W. A., \& Preusser, D. F. (2005) Persistence of effects of the Checkpoints program on parental restrictions of teen driving privileges. American Journal of Public Health, 95(3), 447-452.

Simons-Morton, B. G., Hartos, J. L., Leaf, W. A., \& Preusser, D. F. (2006a). Cognitive mediation of the effect of persuasive materials on parentimposed driving limits of novice young drivers. Journal of Adolescent Research, 21(1), 83-105.

Simons-Morton, B. G., Hartos, J. L., Leaf, W. A., \& Preusser, D. F. (2006b). The effects of the Checkpoints program on parent-imposed driving limits and crash outcomes among Connecticut novice ten drivers at 6-months post-licensure. Journal of Safety Research, 37(1), $9-15$.

Simons-Morton, B. G., Mickalide, A., \& Olsen, E. (2005). Preventing motor-vehicle crash injuries among children and adolescents. In $\mathrm{K}$. Liller (Ed.), Injury prevention for children and adolescents: integration of research, practice, and advocacy. Washington, DC: American Public Health Association.

Simons-Morton, B. G., \& Winston, F. K. (2006). Translational research in child and adolescent transportation safety. Evaluation and the Health Professions, 29(1), 33-64.

Smith, S., Carrington, M., \& Trinder, J. (2005). Subjective and predicted sleepiness while driving in young adults. Accident Analysis and Prevention, 37(6), 1066-1073.

Stevenson, M. R. (2005). Steering in the right direction? Young drivers and road trauma: we need restrictions on night driving and peer passenger numbers for novice drivers. Medical Journal of Australia, 182(3), 102-103.

Stone, L. M., \& Runyan, C. W. (2005). High school off-campus lunch policies and adolescent motor vehicle crash risks. Journal of Adolescent Health, 36(1), 5-8.

Strayer, D. L., \& Drews, F. A. (2004). Profiles in driver distraction: effects of cell phone conversations on younger and older drivers. Human Factors, 46(4), 640-649.

Taubman-Ben-Ari, O., Mikulincer, M., \& Gillath, O. (2005). From parents to children-similarity in parents and offspring driving styles. Transportation Research Part F: Traffic Psychology and Behavior, 8(1), 19-29.

Tilleczek, K. C. (2004). The illogic of youth driving culture. Journal of Youth Studies, 7(4), 473-498.

Ulleberg, P., \& Rundmo, T. (2003). Personality, attitudes and risk perception as predictors of risky driving behavior among young drivers. Safety Science, 41(5), 427-443.

University of California Traffic Safety Center. (2003). Trying to find out why young people drink and drive. Online Newsletter, 1(3), 1-2.

Usdan, S. L., Moore, C. G., Schumacher, J. E., \& Talbott, L. L. (2005). Drinking locations prior to impaired driving among college students: implications for prevention. Journal of American College Health, 54(2), $69-75$.

Vaez, M., \& Laflamme, L. (2005). Impaired driving and motor vehicle crashes among Swedish youth: An investigation into drivers' sociodemographic characteristics. Accident Analysis and Prevention, 37(4), 605-611.

Van Beurden, E., Zask, A., Brooks, L., \& Dight, R. (2005). Heavy episodic drinking and sensation seeking in adolescents as predictors of harmful driving and celebrating behaviors: implications for prevention. Journal of Adolescent Health, 37(1), 37-43.

Victoir, A., Eertmans, A., Van den Bergh, O., \& Van den Broucke, S. (2005). Learning to drive safely: Social-cognitive responses are 
predictive of performance rated by novice drivers and their instructors. Transportation Research Part F: Traffic Psychology and Behavior, $8(1), 59-74$.

Votta, E., \& MacKay, M. (2005). Evaluating the acceptability and feasibility of the I Promise Program: a driving program for families with young new drivers. Injury Prevention, 11(6), 369-372.

Walker, S., Waiters, E., Grube, J. W., \& Chen, M. -J. (2005). Young people driving after drinking and riding with drinking drivers: Drinking locations-What do they tell us? Traffic Injury Prevention, 6(3), 212-218.

Whissell, R. W., \& Bigelow, B. J. (2003). The speeding attitude scale and the role of sensation seeking in profiling young drivers at risk. Risk Analysis, 23(4), 811-820.

Williams, A. F. (2005). Commentary: next steps for graduated licensing. Traffic Injury Prevention, 6(3), 199-201.

Williams, A. F., Ferguson, S. A., \& Wells, J. K. (2005). Sixteen-year-old drives in fatal crashes, United States, 2003. Traffic Injury Prevention, 6(3), 202-206.

Williams, A. F., Leaf, W. A., Simons-Morton, B. G., \& Hartos, J. L. (2006). Vehicles driven by teenagers in their first year of licensure. Traffic Injury Prevention, 7(1), 23-30.

Williams, A. F., Nelson, L. A., \& Leaf, W. A. (2002). Responses of teenagers and their parents to California's graduated licensing plan. Accident Analysis and Prevention, 34(6), 835-842.

Willis, D. K. (2005). Fatal crashes involving 16 year-old texas driver preand post-GDL: Who, when, where, and why? College Station, TX Texas Transportation Institute.

Yannis, G., Golias, J., \& Papadimitriou, E. (2005). Driver age and vehicle engine size effects on fault and severity in young motorcyclists accidents. Accident Analysis and Prevention, 37(2), $327-333$.
Young, K. L., Regan, M. A., \& Mitsopoulos, E. (2004). Acceptability to young drivers of in-vehicle intelligent transport systems. Road Transportation Research, 13(2), 6-16.

Zhao, J., Mann, R., Chipman, E., Adlai, M., Stoduto, E., \& Smart, G. (2006). The impact of driver education on self-reported collisions among young drivers with a graduated license. Accident Analysis and Prevention, 38(1), 35-42.

Richard Compton is Director, Office of Research and Technology, National Highway Traffic Safety Administraton, Washington, DC, where he has over 27 years of experience conducting and directing research in all behavioral traffic safety areas. He received his BA from the University of California-Santa Barbara and $\mathrm{PhD}$ in psychology from the University of Nebraska-Lincoln.

James Hedlund is Principal, Highway Safety North, Ithaca NY; previous work experience includes over 20 years at the National Highway Traffic Safety Administraion. He received his BA from Cornell University and $\mathrm{PhD}$ in mathematics from the University of Michigan. He has published over 60 research studies and journal articles on behavioral traffic safety issues.

Ruth A. Shults is a senior epidemiologist at the Injury Center of the Centers for Disease Control and Prevention (CDC). She coordinates CDC's adolescent driving safety activities and systematic reviews of community-based interventions to reduce alcohol-impaired driving for the Guide to Community Preventive Services. She received her $\mathrm{PhD}$ in epidemiology from the University of North Carolina. 